\title{
PRODUÇÃO DE LEITE E RESISTÊNCIA DA AGRICULTURA FAMILIAR: COMPARANDO DUAS ESTRATÉGIAS DE COMERCIALIZAÇÃO LOCAL NA REGIÃO SUDOESTE DO PARANÁ - BRASIL
}

\author{
MILK PRODUCTION AND THE FAMILY FARM RESISTANCE: \\ COMPARING TWO LOCAL MARKETING STRATEGIES IN \\ SOUTHWEST PARANÁ REGION - BRAZIL
}

\author{
Vinícius Deotan Coletti \\ Secretaria de Estado da Agricultura e do Abastecimento - Curitiba - PR - Brasil \\ Miguel Angelo Perondi \\ Universidade Tecnológica Federal do Paraná - Pato Branco - PR - Brasil
}

\begin{abstract}
Resumo: Contrariando muitas análises de economistas e pensadores "globalizados", a agricultura familiar vem persistindo e se diversificando. Esse estudo procura explicar as relações da agricultura familiar com o mercado, sua resistência e reprodução no meio rural. Regiões como o Sudoeste do Paraná, Oeste de Santa Catarina e o Noroeste do Rio Grande do Sul são caracterizadas pela predominância de propriedades rurais familiares. Nessas regiões, a produção leiteira é predominante, mas desenvolve-se de forma heterogênea no que diz respeito aos sistemas de produção e às estratégias de comercialização. Neste artigo, realizou-se uma revisão bibliográfica acerca do tema, bem como, um estudo de caso em duas propriedades familiares que têm o leite como uma de suas principais estratégias de reprodução social e que comercializam seus produtos diretamente ao mercado consumidor, no mercado local e garantindo melhores rentabilidades com a atividade.
\end{abstract}

Palavras-chave: Agricultura familiar. Resistência. Estratégias de comercialização. Agregação de valor.

Abstract: Contrary many analyzes of economists and thinkers "globalized", family farming has persisted and diversifying. This study seeks to explain the relationship of family farming with the market, its strength and social reproduction in rural areas. Regions like the Southwest Paraná, Santa Catarina West and the Northwest of Rio Grande do Sul, are characterized by the predominance of family farms. In these regions, milk production is predominant, but develops unevenly, with regard to production and marketing strategies systems. In this article we carried out a literature review on the subject as well as a case study in two family farms that have milk as one of its main strategies of social reproduction and sell their products directly to the consumer market, the local market and ensuring better returns with activity.

Key Words: Family farming. Endurance. Marketing strategies. Adding value.

\section{INTRODUÇÃO}

A agricultura familiar vem, ao longo do tempo, buscando resistir e se reproduzir no mundo globalizado, explorando sua relação com a sociedade e o mercado envolvente que pressiona e afeta diretamente o seu desenvolvimento. Isso reflete na escolha das estratégias adotadas, integrando o seu conhecimento prático e de vida com as indagações enfrentadas como "o que, como e para quem 
produzir", em busca de produzir alimentos e gerar renda para que possam sobreviver e se reproduzir com progresso social e econômico.

A agricultura familiar possui uma estreita relação com a produção de leite. Uma grande parcela desses agricultores utiliza a atividade de produção de leite nas suas estratégias de reprodução social. Existe uma imensa heterogeneidade no desenvolvimento da atividade leiteira e sua composição na renda familiar, bem como, sobre o sistema de manejo, grau de tecnologia e intensificação empregados, produtividade e inserção no mercado.

A produção leiteira no Brasil vem crescendo constantemente e está inserida num contexto de elevada produção mundial. Em 2008, foram produzidos mais de 578 bilhões de litros de leite no mundo (FAO - Organização das Nações Unidas para Agricultura e Alimentação citado por ALVES, 2010). Segundo o mesmo documento, os Estados Unidos lideram o ranking de países produtores, seguido da Índia, China, Rússia e Brasil (cinco maiores produtores). Entretanto, esses países consomem grande parte da produção no seu mercado doméstico. A produção de leite tem um papel fundamental em todas as economias, especialmente em países em desenvolvimento, porque, além de envolver o componente econômico, o leite é considerado um produto essencial para a população desses países. (ZOCCAL, GOMES e CARVALHO, 2004).

Em 2008, foram produzidos aproximadamente 27,58 bilhões de litros de leite no Brasil, apresentando um aumento de 5,5\% no ano sobre o volume registrado em 2007 e um consumo interno per capita de 146 litros (IBGE, 2008). Vale destacar que, nesse período, o Brasil já era considerado autossuficiente na produção de leite e, até então, com mercado em franca expansão. Já em 2013, a produção de leite no Brasil chegou a 34,25 bilhões de litros (IBGE, 2013). Em cinco anos (2008-2013) houve um crescimento de 24,18\%, ou seja, 4,83\% ao ano. Percebe-se, dessa forma certa retração no crescimento da produção nacional no período de tempo analisado.

A região Sul do Brasil e sua produção de leite têm se destacado nacionalmente. O Paraná e o Rio Grande do Sul vêm disputando, ano a ano, o status de segundo maior produtor de leite do país. O Paraná, com uma produção de 4,34 bilhões de litros, o que corresponde a 12,7\% da produção nacional, ainda apresenta uma produtividade média por vaca considerada baixa. Entretanto, nos últimos 15 anos (1997 - 2013), houve um crescimento expressivo da produção de leite no Brasil, que passou de 18,7 bilhões de litros para 34,25 bilhões de litros, apresentando um crescimento de $83,15 \%$, enquanto a produção do Paraná passou de 1,6 bilhões de litros para 4,34 bilhões de litros, apresentando um crescimento de 171,25\%. Em um ano (de abril de 2007 até março de 2008), a quantidade de leite industrializado no estado cresceu $21,5 \%$, mesmo enquanto o preço médio anual pago pelo litro foi de R\$ 0,62 (IBGE, 2008, citado por BATTAGLINI et al, 2009). E o preço continua a subir. Um exemplo é que, no ano de 2011, o preço médio pago no Sul do Brasil foi de aproximadamente $R \$ 0,80$, nos anos de 2013 e 2014 seguiu subindo, chegando a mais de R\$ 1,00 por litro de leite. Entretanto, em 2015, esse cenário vem mudando e os preços retrocedendo aos patamares de $\mathrm{R} \$ 0,80$ a $\mathrm{R} \$ 0,90$ por litro. 
A região Sudoeste do Paraná contempla 42 municípios e vem se destacando nessa atividade, crescendo em produtividade e área. Essa região apresenta uma das maiores densidades de produção de leite do país, registrando, em 2008, a produção de 815 milhões de litros (DERAL/SEAB, 2009). Segundo dados do Departamento de Economia Rural - DERAL vinculado à Secretaria de Estado da Agricultura e Abastecimento - SEAB do Paraná, em 2013, a produção de leite desses 42 municípios ultrapassou a marca de 1,1 bilhão de litros e mais de $26 \%$ da produção estadual. Esses dados situam essa região entre as 15 mesorregióes com maior produção de leite do Brasil e com a vantagem de ainda apresentar um grande potencial produtivo a ser desenvolvido e com competitividade.

A agricultura familiar, que tem como principal atividade o leite, difere individualmente no que diz respeito à condição tecnológica de manejo, alimentação, à ordenha e ao armazenamento. A comercialização é feita, geralmente, em laticínios que processam o leite utilizando tratamentos térmicos como a pasteurização. Contudo, algumas famílias transformam, beneficiam, embalam e comercializam o leite, buscando a agregação de valor. Esses processos são feitos na própria propriedade, comercializando o leite no mercado local de forma direta ao consumidor ou em feiras, passando por processos tecnológicos de pasteurização e envase ou não, transformando o leite cru apenas refrigerado.

Assim, muitos produtores comercializam o leite e seus subprodutos em vias alternativas, resistindo aos processos de intensificação e modernização da produção, contudo, à margem da fiscalização, a qual exige o tratamento térmico. Esses produtores buscam atender à demanda de uma parcela de consumidores que procura preços mais baixos ou por opção, por preferirem produtos menos processados, quando há confiança sobre os processos de quem produz. Segundo Wilkinson \& Miro (1999), o setor informal ocupa um espaço significativo em várias cadeias de consumo popular: $40 \%$ no leite, $50 \%$ na carne bovina, $10-20 \%$ nas carnes brancas. Assim, uma preocupação recorrente na atividade leiteira é sua qualidade, pois o mercado informal dificilmente faz tratamentos térmicos, visando à eliminação de micro-organismos patogênicos, requerido pela legislação na NORMATIVA No 51, DE 18 DE SETEMBRO DE 2002 (BRASIL, 2002). Os produtores de leite da Região Sudoeste apresentam um universo diversificado no que diz respeito às vias de comercialização. A maioria realiza a venda aos laticínios, entretanto, alguns buscam alternativas que melhorem a renda da atividade.

Dessa forma, o objetivo deste trabalho é o de discutir por meio de revisão bibliográfica, as relações entre a resistência da agricultura familiar nos mercados globalizados e a importância da produção e comercialização de leite para sua sobrevivência nos dias atuais. Para tanto, procurar-se-á analisar duas estratégias alternativas de resistência dos agricultores familiares do Sudoeste do Paraná que têm como atividade principal o leite, e que fazem a comercialização direta no mercado local. Em específico, procurar-se-á comparar: (1) as estratégias produtivas adotadas até a comercialização e (2) os aspectos econômicos relacionados aos processos estabelecidos. 


\section{METODOLOGIA}

Essa pesquisa se caracteriza, segundo Marconi e Lakatos (2002); Silva e Menezes (2001) citados por Bigaton, Polo \& Escrivão Filho (2007), como uma pesquisa qualitativa, uma vez que tem por objetivo descrever e explicar determinado fenômeno. Com relação aos meios de investigação sobre os parâmetros de qualidade, far-se-á um estudo comparativo de caso, pois se propõem a analisar uma parcela representativa de produtores com o intuito de compará-los em relação à qualidade dos seus produtos, os procedimentos adotados e a que mercados são destinados e, assim, enriquecer o aprendizado e a pesquisa.

Os produtores foram entrevistados visando obter informações/dados para a análise econômica e produtiva da atividade leiteira. Os meses avaliados foram de Agosto 2009 a Março 2010, com base nos dados obtidos pelo projeto Redes de Referências para a Agricultura Familar. Além da entrevista nas visitas aos estabelecimentos, foi realizado o acompanhamento do processamento e embalagem do produto a ser comercializado.

Este trabalho foi realizado em duas propriedades localizadas na região Sudoeste do Paraná, nos municípios de Itapejara d'Oeste e Verê. As duas famílias produzem leite e fazem sua comercialização direta ao consumidor ou em locais de venda. O produtor de Itapejara d'Oeste, denominado neste trabalho como Produtor A, produz leite e o comercializa sem realizar nenhum tratamento térmico. O leite é envasado em garrafas PET e distribuído de porta em porta diariamente pelo produtor, com o uso de uma motocicleta com caixa isotérmica. Já o produtor de Verê, denominado produtor B, produz seu leite e realiza pasteurização lenta, utilizando a estrutura da associação de produtores da comunidade, localizada na sua propriedade, e embala seu produto (leite e nata) em saquinhos "barrigamole". A venda é feita diretamente ao consumidor, no mercado do produtor, nas sorveterias e panificadoras e, também, para o mercado institucional (modalidade de compra feita pelo governo) que visa o abastecimento de hospitais, escolas, entre outras instituições públicas de assistência. Esse produtor possui Serviço de Inspeção Municipal - SIM, o que lhe permite acessar o mercado institucional.

O principal instrumento de pesquisa foi a entrevista semiestruturada com os interlocutores-chave, utilizando-se de um roteiro padronizado, com questões gerais adaptadas de acordo com a ocasião. Também foram utilizados dados econômicos das duas propriedades assistidas pelo programa de Gestão da Pecuária Leiteira, versão 2004, e dados obtidos por meio do acompanhamento da equipe de pesquisadores de instituições de pesquisa e extensão da região (IAPAR e EMATER), durante o período selecionado, de agosto de 2009 a março de 2010. Esses dados são importantes para a análise e comparação dos custos, receitas e lucros obtidos, conforme a variação de preços do mercado, seja do leite ou de insumos e commodities.

\section{O LEITE COMO FOCO DA AGRICULTURA FAMILIAR NO SUL DO BRASIL}

Concorda-se com Lamarche (1993, p. 18) quando afirma que: 
à exploração familiar se organiza em torno de um eixo definido pelo grau de integração ao mercado. Muitos agricultores familiares têm desaparecido ou porque não conseguem se adaptar às novas exigências do mercado ou porque se encontram desprovidos de todo o seu patrimônio sócio-cultural. Perdendo esse patrimônio, perde-se um capital de conhecimento que poderia ser utilizado para encontrar soluções alternativas.

Contrariando muitas análises de economistas e pensadores "globalizados", em algumas regiões, as propriedades familiares vêm persistindo e se diversificando, utilizando estratégias e atividades que podem torná-la pluriativa. Esses agricultores são alvos de pesquisa científica, que procura explicar suas relações com o mercado, sua resistência e reprodução no meio rural. Regiões como o Sudoeste do Paraná, Oeste de Santa Catarina e o Noroeste do Rio Grande do Sul são caracterizadas pela predominância de propriedades rurais familiares e pelas quais muitas estratégias desenvolvidas têm se destacado por serem iniciativas que (re)valorizam - local e as produções alternativas que agregam valor, sejam elas tradicionais, ecológicas, a agroindustrialização, o turismo, entre outras. Essas formam o universo de atividades desenvolvidas por essas famílias, que podem ser várias ao mesmo tempo, o que pode, de certa forma, explicar sua reprodução, principalmente por suas características de diversificação da produção.

Muitas estratégias que obtêm sucesso entre os agricultores familiares se referem não exclusivamente a inovações ou novidades, mas, sim, a um resgate pelo consumo de produtos tradicionais, menos processados e industrializados, refletindo a existência de laços de confiança na comercialização local e em canais alternativos. No mercado local, o produtor é conhecido e seu produto facilmente "rastreado" e valorizado (quando se destaca pela sua qualidade e reputação), sendo, assim, socialmente reconhecido. Dessa forma vários novos mercados vêm em constante evolução. Mesmo assim, muitas vezes, o tradicional produto da agricultura familiar, historicamente produzido e reconhecido, pode ser proibido de acessar os mercados locais, uma vez que a legislação brasileira, no que diz respeito aos produtos familiares e os mercados locais, é extremamente exigente e intransigente. Feitos sob moldes tecnicistas, muitos parâmetros exigidos ignoram as realidades locais e, assim, limitam a possibilidade de explorar esses mercados locais de produtos frescos. Indaga-se a necessidade de tamanha rigidez sem que haja pesquisa para saber se são riscos à saúde do consumidor, estabelecer limites qualitativos a fim de viabilizar esses mercados da Agricultura Familiar e garantir a segurança dos produtos.

O caso do leite é uma questão na qual pode ser facilmente visualizado esse problema. A bovinocultura leiteira é representada, em grande parcela, pelos agricultores familiares do Sul do Brasil, onde se concentra grande parte da produção nacional, mais especificamente no território que abrange a região Noroeste do Rio Grande do Sul, Oeste de Santa Catarina e Sudoeste do Paraná. Esta última, como veremos mais adiante, representará o universo desta pesquisa. A produção de leite tem se desenvolvido muito nos últimos anos, incentivada pelos preços atrativos e a fácil adaptação da agricultura familiar à rotina dessa atividade. 
Nessa região, existe um histórico de integração às grandes agroindústrias, ressaltando que, comumente à crise na produção de suínos, muitos desses produtores já vinham trabalhando com o leite, mesmo que apenas para consumo.

Com o aumento dos preços e a formação de uma cadeia produtiva consolidada, muitos veem uma oportunidade na atividade leiteira e, assim, a região Sudoeste do Paraná tem se destacado como grande produtora de leite. $\mathrm{O}$ crescimento da participação dessa atividade na renda agrícola desses produtores é evidente, e, impulsionados por essa remuneração compensatória e mensal, os produtores familiares têm (re)valorizado a produção de leite. Assim, vêm se destacando e ganhando uma maior dedicação a essa atividade que antes era marginalizada. Essa região vem crescendo em produtividade e em área destinada à produção de leite. Contempla 42 municípios, nos quais se concentra uma das maiores densidades da produção de leite do país e registrou, em 2008, a produção de 514 milhões de litros (IBGE, 2008). Em 2010, dados oficiais contemplam essa

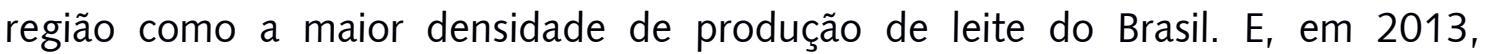
segundo a SEAB/DERAL, a região ultrapassou a marca de 1 Bilhão de litros de leite produzidos.

A forte presença da agricultura familiar nesse contexto e sua diversidade e heterogeneidade de estratégias que buscam desenvolver para se reproduzir social e economicamente no mundo capitalista globalizado atual representam uma resistência ao sistema de produção historicamente priorizado. Ao se implantar, trouxe inúmeros problemas ambientais, econômicos e sociais a um enorme contingente de produtores que não aderiram e esse novo estilo de se fazer agricultura, denominado Revolução Verde. Os que resistem até os dias de hoje buscam na diversidade e na venda dos excedentes, sua sobrevivência, integrados em vários níveis ou não ao mercado. No caso do Sudoeste paranaense, também podem estar inseridos no mercado por intermédio das grandes agroindústrias presentes (BRFoods, Coasul), bem como médias (Agrogen, Frango Seva, Pluma Agroavicola), de frigoríficos - pela integração com aves e suínos - ou alternativamente pela agroindustrialização de produtos diferenciados na propriedade. Nesta última, buscam, por meio dessas atividades, obter maior rentabilidade, comercializando seus produtos diretamente ao consumidor. Contudo, o mercado e os processos, até chegarem a eles, muitas vezes podem impedir ou impossibilitar o desenvolvimento dessas atividades. As restrições financeiras, tecnológicas e a constante atualização ou exigências podem minar essas estratégias. Por isso, indaga-se: de que forma são avaliados esses produtos? Será que são avaliados? Quais os parâmetros para se analisar a qualidade? Que estrutura e procedimentos são necessários para obter?

\section{A BUSCA PELO SENTIDO DO LEITE NO MERCADO LOCAL}

Atualmente existe uma grande heterogeneidade nas estratégias utilizadas pelos produtores familiares na produção e comercialização do leite (e seus produtos). Muitas delas ocorrem em em vias alternativas aos Sistemas de Inspeção, além de que, muitos municípios ainda nem oferecem um serviço de inspeção aos produtores e aos consumidores municipais. Assim suas estratégias podem ser 
ofuscadas pela fiscalização que exige o tratamento térmico, mas, principalmente, pela falta de pesquisas na área da Segurança Alimentar, em específico, sobre os processos e a qualidade dos produtos da pequena produção familiar que são oferecidos em cadeias curtas e consumo fresco no mercado local. Uma estratégia alternativa que poderia garantir a qualidade do leite sem colocar em risco a saúde do consumidor seria a adoção de Boas Práticas Agrícolas - BPA e de Boas Práticas de Higiene na Ordenha - BPHO. A aplicação dessas práticas desde a produção, com os devidos controles, dispensa até mesmo a necessidade de pasteurização ou esterilização para garantir a segurança alimentar para o mercado local, como se observa nos países da Comunidade Europeia. Contudo, aqui no Brasil ainda não há um reconhecimento, uma instituição ou um aparato legal que fiscalize e que certifique esses produtos, como os fazem na União Europeia.

A legislação brasileira proíbe a comercialização do leite cru para o consumo sem que haja um tratamento térmico para a eliminação de micro-organismos patogênicos. Entretanto, a hipótese é de que, considerando as BPA e a qualidade garantida na propriedade, assim como a que é feita na Europa, que possui uma legislação e um sistema de gestão da qualidade em todos os setores produtivos, garantiria a comercialização do leite cru sem oferecer risco ao consumidor. A possibilidade de processá-lo sem tratamentos térmicos seria importante, pois essa prática obrigatória altera as características sensoriais do leite e dos seus derivados, além de inserir uma gama de produtores familiares no mercado local, obtendo melhores rendimentos.

$O$ estudo sobre as diferentes estratégias adotadas permite reconhecer similitudes na cadeia produtiva, possibilitando o desenvolvimento de políticas públicas voltadas para esses produtores, por meio do estudo de suas demandas, buscando facilitar o acesso aos mercados, proporcionando maior rentabilidade e um produto final de valor agregado e qualidade superior, beneficiando, também, os consumidores que adquirem um produto seguro e de excelente qualidade. Sendo assim, o estudo da atividade é de suma importância para o desenvolvimento da região Sudoeste do Paraná e dos produtores que utilizam dessa estratégia para sobreviverem.

Uma hipótese é que as propriedades familiares utilizam a produção de leite como estratégia de reprodução por se adaptarem ao manejo e à rotina dos animais e por ser uma atividade conhecida e com sistemas parecidos aos sistemas de integração já vivenciados. Dessa forma, a produção de leite é favorecida pela conjuntura da unidade de produção familiar. A disponibilidade de mão de obra, a divisão das responsabilidades, a redução dos custos de produção e o manejo diferenciado proporcionam rentabilidade e produtos mais íntegros e saudáveis.

Os mercados locais remetem a relações pessoais, um vínculo entre produtor e consumidor, o qual conhece a origem do produto e há possibilidade de um contato com o processo de produção pela aproximação entre ambos. Não existe uma instituição que detenha autonomia e poder para certificar e reconhecer essa origem, processo socialmente construído e que, muitas vezes, é impedido pelo próprio Estado. A legislação desatualizada que, por não haver investimentos consideráveis em pesquisa, ensino e extensão, não evolue com a mesma velocidade que os aumentos de produção e formas de produzir. A ação do Estado 
se reduz à fiscalização da legislação atual, que proíbe essa comercialização direta. Mas a mesma lei que se preocupa com a sanidade também não permite e nem incentiva a criação de instituições que tenham respaldo e que certifiquem a produção da agricultura familiar. O que limita e influencia o que produzir, direcionando a produção para a demanda do mercado e, principalmente, ao mercado de commodities.

Ao mesmo tempo, outras estratégias vêm sendo desenvolvidas por alguns agricultores no sentido de produzir e agregar valor concomitante, buscando produtos e mercados alternativos aos hegemônicos, por meio de seu capital social e do seu conhecimento sobre os procedimentos e processos que proporcionam a reprodução e a resistência da agricultura familiar no mundo mercantilizado do capital globalizado.

Concordando com Escher (2011, p. 200), ao se referir à atividade leiteira, que:

(...) apesar de assumir uma importância certamente diferenciada no período posterior a década de 1990, a atividade leiteira é praticada há mais de cinquenta anos no Sudoeste. Desde a década de 1970 a venda direta de leite ao consumidor vinha assumindo uma importância significativa na vida econômica dos colonos, que dirigiam-se até as imediações urbanas para "entregar" os seus produtos - sobretudo nas cidades com maior densidade e crescimento populacional, como Francisco Beltrão, Pato Branco e Dois Vizinhos - e assim, gradualmente construindo um capilarizado "mercado informal" de leite, articulado na forma de "cadeias curtas de alimentos", bastante representativas até os dias de hoje, através das "feiras livres" e principalmente do "leiteiro" que faz entrega à domicilio em garrafas pet.

Essas relações comerciais assentam-se, sobremaneira, em relações de confiança entre os produtores e os consumidores, que são indiferentes às questões de regulamentação legal-sanitária, pois a qualidade do produto é reconhecida e valorizada por atributos diferentes daqueles priorizados pela legislação. Os consumidores reconhecem atributos específicos e valorizam o produto, por exemplo, por ser "um leite fresco", ou "um leite gordo", ou "um leite mais saudável". E, além dessas especificidades do produto, obviamente surgem e se atribuem relações que envolvem fatores como a amizade, o interconhecimento e a reputação.

Ploeg (2007) aponta para formas de resistência criadas enquanto desvios da gramática ditada pelo controle "imperial", que caracterizam e estruturam os processos de trabalho e produção:

são formas de resistência que se materializam nos espaços de produção, através de alterações nos hábitos e rotinas, nos ritmos e processos de trabalho, nas formas de cooperação, nos tipos de materiais e de produtos utilizados, nos diferentes mercados e canais de comercialização em que os agricultores se inserem. Estes repertórios culturais e materiais são alterados de acordo com as diferentes experiências, interesses, preferências, procedimentos, aptidões e práticas dos agricultores (PLOEG, 2007). 
Essas estratégias de resistência dos agricultores não se restringem aos espaços privados de trabalho e produção e revelam-se na capacidade que os agricultores têm para produzir inovações técnicas e organizacionais que se traduzem em alternativas concretas para a construção das trajetórias de diversificação de seus meios de vida e dos territórios em que vivem e se reproduzem. Mas claro que as estratégias não estão desconectadas e nem desarticuladas das estruturas sociais (econômicas, políticas, culturais) em que se inserem.

Novos bens e serviços eram e são criados, porque os principais mercados para os produtos padronizados apresentam falhas sistemáticas (devido, entre outras coisas, à posição central dos impérios alimentares na governança desses mercados). Portanto, a construção de novos mercados emerge como uma arena importante (assim como o distanciamento de outros mercados, como o de agroquímicos, e o desenvolvimento de novas formas de governança para os mercados existentes) (PLOEG, 2011).

Certamente ocorrem, nesse processo, inúmeros conflitos, podendo ser legislativos, operacionais, informativos ou culturais. Dessa forma, há que evoluir gradualmente, com um trabalho amplo e ao mesmo tempo local, buscando se adaptar às mudanças da sociedade, garantindo a produção como meio de vida e o consumo seguro.

É nessa construção de estratégias, de ganhar poder nos seus espaços de vida e de atuação, criando alternativas ao que lhes é imposto, que os agricultores familiares têm afirmado sua singular relevância no cenário nacional. Graças a essas estratégias e ao seu protagonismo, grupos desses agricultores têm contribuído para a revitalização dos espaços rurais e reconstrução da ruralidade, ressignificando o que é viver no rural pelas sociabilidades que mantêm e constroem, pelas referências ambientais de que se apropriam e pela sua inserção num projeto societário de sustentabilidade e de desenvolvimento solidário. (FERREIRA et al., 2007).

Dessa forma, Escher (2011) coloca que parece evidente que a produção de novos bens e serviços pressupõe, ao final, a construção de novos mercados (uma vez que sua comercialização por intermédio de amplos mercados de commodities seria impraticável ou implicaria uma grande expropriação do valor agregado encerrado nesses novos produtos e serviços).

De acordo com PLOEG, (2011, p. 122):

(...) há novos mercados emergindo. Estes são mercados particularmente diferentes dos mercados de commodities. Os novos mercados emergentes centram-se, muitas vezes, na demanda por e distribuição de produtos e serviços que portam um diferencial. Eles diferem dos demais que circulam nos mercados de commodities: a qualidade é superior; a origem é conhecida (se comparada aos produtos anônimos dos mercados de commodities); sua produção é diferente e incorpora características específicas no produto; incorporam relações diferentes entre produtores e consumidores; representam diversos graus de acessibilidade; etc.

Para que haja uma (re)valorização da agricultura familiar, Abramovay (2000) coloca que projetos de desenvolvimento terão tanto mais chances de 
sucesso quanto mais forem capazes de extrapolar um único setor profissional. Para o autor, o desenvolvimento territorial apoia-se, antes de tudo, na formação de uma rede de atores trabalhando para a valorização dos atributos de uma certa região. É esta rede que permite a existência de uma dinâmica de "concorrênciaemulação-cooperação" entre as empresas de uma certa região. Esta articulação pode ser feita em torno de ideias, em princípio, muito simples, mas cuja realização prática supõe uma densa rede de relações locais. Exemplo: Consumo dos queijos dos campos de cima da Serra no Rio Grande do Sul e dos queijos coloniais na região Sul e, incluindo outros exemplos, consumo do queijo coalho por turistas no litoral do nordeste e o queijo do Serro mineiro, feito com leite cru, e tantos outros bem menos famosos mas que vem servindo de alimento para sua sobrevivência há muito tempo.

O autor faz referência aos estudos de Beccattini e o desenvolvimento do norte da Itália, que, por meio de um enfoque territorial, explorou suas "riquezas" e possibilitou o desenvolvimento valorizando as atividades desenvolvidas localmente. Ainda enfatizou sobre iniciativas de regiões que tentaram se organizar de forma cooperativa como o Pacto Nova Itália no Sudoeste do Paraná e, no Oeste de Santa Catarina, o Pacto de Desenvolvimento Regional Integrado.

Embora em menor escala que nos países europeus, o modelo produtivista começa a ser questionado no Brasil. O movimento da agricultura alternativa apresenta uma grande vitalidade e repousa no crescimento do número de consumidores preocupados com a qualidade dos alimentos. No entanto, o perfil de renda da população urbana constitui ainda um freio para a generalização dessa expectativa de consumo: as preocupações ante a qualidade não ultrapassam a questão central do próprio acesso à alimentação. (FERREIRA, et al. 2007).

Do ponto de vista do consumidor, ascende a preocupação com a saúde, o consumo politizado e a busca por produtos mais saudáveis e íntegros. Há uma tendência na opção por produtos menos industrializados, produzidos em cadeias curtas e localizadas, o que remete a segurança/confiança.

Isso vem abrindo portas, novos canais de mercados e relações vêm se construindo, um resgate de produções tradicionais, anteriormente relacionadas apenas para o consumo familiar, mas que, devido ao interesse de uma parcela da população, opta por produtos artesanais. Estes são menos processados (homogeneizados), que remetem a particularidades de um local e/ou um processo de produção, valorizando-os em relação aos enlatados e esterilizados industrializados. Mercados que, muitas vezes, ultrapassam barreiras legislativas, as quais devem se adequar para possibilitar a comercialização de um produto seguro. Há muito vem se discutindo uma adequação da legislação, de forma que não barre a entrada de produtos de qualidade e que permita, da mesma forma, a produção e comercialização pela agricultura familiar. Relata-se que, muitas vezes, sob o ponto de vista da legislação sanitária vigente, poderiam estar fora de padrões de estrutura física mínima necessária, por exemplo.

Estima-se que $40 \%$ do consumo de leite é abastecido pelo mercado informal. Segundo Wilkinson \& Mior (1999), no mundo acadêmico e nos organismos internacionais existem várias definições do setor informal, como também, avaliações positivas e negativas do seu significado. Num extremo, ele 
pode ser identificado com a pobreza e/ou a sonegação, enquanto, noutro, vários autores veem o setor informal como uma reação criativa à burocracia estatal e à inadequação na provisão de serviços, tanto públicos como privados. Ainda segundo os mesmos autores, o setor informal distingue-se do ilegal pelo fato de seus produtos não serem proibidos, como no caso de drogas ou contrabando. Trata-se de uma atividade cujos processos de produção não se enquadram nos padrões de regulação vigentes. Isso pode se referir às relações de trabalho (sem carteira, trabalho infantil), às instalações (sem alvará) ou às normas técnicas de produção (não adequação ao regulamento industrial e sanitário). Enquanto no primeiro caso o órgão repressor apropriado é a policia, no segundo, os organismos de fiscalização são responsáveis pelo enquadramento. O setor informal, portanto, é definido fundamentalmente a partir das normas reguladoras do Estado. Ao mesmo tempo, o termo pode se estender a atividades que não reconhecem normas e práticas adotadas por grupos organizados da sociedade civil (grêmios, associações de classe, etc.). Nesse caso, sanções sociais podem substituir a falta de instrumentos legais de repressão (WILKINSON \& MIOR, 1999).

Deves \& Filippi (2008) citam Sonnino \& Marsden (2006) quando procuram compreender os processos de redes agroalimentares alternativas, onde o eixo central é o "embededness", ou seja, enraizamento, para, inclusive, a qualidade.

Segundo os autores:

\begin{abstract}
tomando como experiências, o norte e o sul da Europa, onde ao sul se desenvolveu basicamente através da valorização das práticas e cultivos e as paisagens locais. Nesta região, predomina o conceito de qualidade baseado em propriedades organolépticas e em processos de produção culturalmente definidos. Já ao norte, a visão de qualidade se detém na observância da legislação e de padrões de higiene. O que queremos destacar é que na prática, o elemento central da rede de alimentação alternativa, se refere ao enraizamento, que é um instrumento teórico muito útil para relacionar alimento com território.
\end{abstract}

Para tanto, segue-se o trabalho apresentando dois casos alternativos de resistência dos agricultores familiares do Sudoeste do Paraná que possuem o foco no comércio local do leite via diferentes estratégias de comercialização.

\title{
5 COMPARANDO DUAS EXPERIÊNCIAS DE COMÉRCIO LOCAL DO LEITE
}

As estratégias de comercialização e renda da atividade leiteira dos produtores A e B serão descritos e analisados a seguir.

\subsection{Estratégias do Produtor A}

Este produtor, conforme dados obtidos em entrevista, visita in loco e análise de dados, em termos de infraestrutura e disponibilidade de terra, representa uma parcela significativa de produtores de leite da região Sudoeste do Paraná. Apresenta uma pequena área própria, mão de obra familiar, com produção de leite predominantemente a pasto. O diferencial deste produtor é a estratégia adotada 
para comercializar o produto. O produtor A ordenha suas oito vacas, resfria o leite, faz o envase em garrafas PET de dois litros e vende a uma rede de consumidores fixa com entrega a domicílio. Com isso, desenvolveu uma rede de consumidores que consomem, em média, dois litros a cada dois dias, um litro de leite por dia para cada família. A entrega é feita diariamente, por meio de uma motocicleta com uma caixa isotérmica adaptada e percorrendo um trajeto médio de sete $\mathrm{km}$ entre a propriedade e o consumidor. O excedente de leite é entregue ao laticínio.

É um produtor muito preocupado com a qualidade, tem orgulho em repetir que seu leite nunca deu problema de contaminação e afirma que nunca algum cliente reclamou da qualidade do seu produto.

O produtor A apresenta uma área total de 4,80 ha, sendo a Superfície Agrícola Útil - SAU igual a 2,7 ha. Nessa área, o produtor possui 2,0 ha de pastagem perene e 0,7 ha arrendados e utilizados em integração lavoura-pecuária, com milho silagem no verão e pastagem anual no inverno. Este produtor possui 16 animais, dos quais cinco são vacas em lactação, cinco vacas secas, quatro novilhas de um a dois anos e duas bezerras até um ano. De capital, o produtor possui uma sala de ordenha, um estábulo de alvenaria, um galpão de madeira, uma ordenhadeira mecânica, um resfriador de imersão, uma ensiladeira, um forrageiro e uma carreta de tração mecânica. O produtor mantém seus animais, principalmente na pastagem perene, fornecendo ração para as vacas em lactação. Durante o inverno, pela baixa produção da pastagem perene, há necessidade de suprir essa demanda com pastagem anual de inverno, a qual é composta por aveia e azevém. Isso diminui os custos com ração, por serem forrageiras de excelente qualidade nutricional.

O custo deste produtor, no que se refere à alimentação dos animais, soma em média $R \$ 125,00$ por mês, o que pode variar conforme o mês e a quantidade de vacas em lactação. A pastagem perene recebe adubações conforme a necessidade, podendo ser adubação via compostos orgânicos, como cama de aviário curtida ou esterco bovino, e via adubação mineral. Durante o período avaliado, foi feita uma adubação orgânica com $65.000 \mathrm{Kg}$ de composto orgânico e duas aplicações de uréia, a um custo total de $R \$ 507,00$ para dois ha. A pastagem anual de inverno recebe um investimento de $R \$ 313,00$ e proporciona cerca de $30.000 \mathrm{Kg}$ de pasto para o consumo das vacas, a um custo de $\mathrm{R} \$ 0,0149$ por $\mathrm{Kg}$ de pasto. Além desses custos, ainda são computados gastos com sal mineral e comum, medicamentos, assistência veterinária quando necessária e outras despesas variáveis. Deve-se adicionar ao cálculo do custo o gasto com combustível da moto para entregar o leite, que consome aproximadamente nove litros de gasolina por mês, que correspondem a $R \$ 25,00$ (no ano da pesquisa). E essa moto tem uma caixa isotérmica acoplada atrás do banco para manter o leite em baixa temperatura enquanto realiza as entregas.

O produtor tenta manter o máximo de tempo possível as vacas na pastagem perene, adubando-a quando necessário. Quando o inverno se aproxima, a produção de pasto diminui até quase zerar. Enquanto isso, há a implantação da pastagem anual de inverno. Se não for bem planejada, pode acarretar prejuízos durante o período conhecido como vazio forrageiro, ou seja, o período em que não há pastagem disponível, o que interfere na alimentação, exigindo maior 
fornecimento de ração e elevando os custos de produção. Porém, quando em condições de pastejo, a pastagem anual de inverno proporciona um pasto de qualidade e em quantidade adequada para uma boa produção de leite a custo baixo. O produtor pretende fazer silagem de milho na próxima safra, entretanto, neste levantamento, forneceu somente ração para as vacas em lactação, em média $250 \mathrm{Kg}$ de ração por mês, variando conforme o mês e a necessidade pela disponibilidade ou não de pasto de qualidade, que é priorizado, uma vez que é o alimento mais barato e que reduz custos.

A produção de leite é refrigerada e envasada para a comercialização direta e o excedente é vendido ao laticínio. Sua produção mensal média durante o período analisado foi de 1.395 litros, com uma produtividade média por vaca lactante de 9,3 litros por dia. O preço obtido por esse produtor nos meses analisados diferencia em relação ao que é vendido direto e ao que é vendido ao laticínio. No caso do leite vendido diretamente ao consumidor, o preço pago foi fixo - $R \$ 1,50$ por litro - no período analisado. Já o leite vendido ao laticínio variou o preço pago, que, em média, foi de $R \$ 0,5325$ por litro. A média do que foi vendido diretamente ao consumidor nos meses avaliados foi de 1.019 litros por mês ao preço de $R \$ 1,50$, proporcionando uma Renda Bruta - RB de $R \$ 1.528,50$. E a média do que foi vendido ao laticínio foi de 306 litros por mês, a um preço médio pago de $R \$ 0,5325$, durante o período de estudo, proporcionando uma RB média mensal de $R \$ 162,95$. Para fazer uma comparação, considera-se que todo o leite que é vendido direto ao consumidor fosse vendido ao laticínio, ou seja 1019 litros $x R \$ 0,5325$, proporcionaria uma $R B$ igual a $R \$ 542,62$. Comparando a $R B$ do leite vendido diretamente, há uma diferença de $R B$ de $R \$ 985,88$ do total de $R B$ do leite vendido diretamente, que representa aproximadamente $282 \%$ da RB do leite caso este fosse vendido exclusivamente ao laticínio. Os valores estão contidos no Gráfico 1.

Gráfico 01. Gráfico hipotético comparando a RB obtida do leite vendido diretamente ao consumidor com a RB do mesmo leite vendido ao laticínio do produtor $\mathrm{A}$

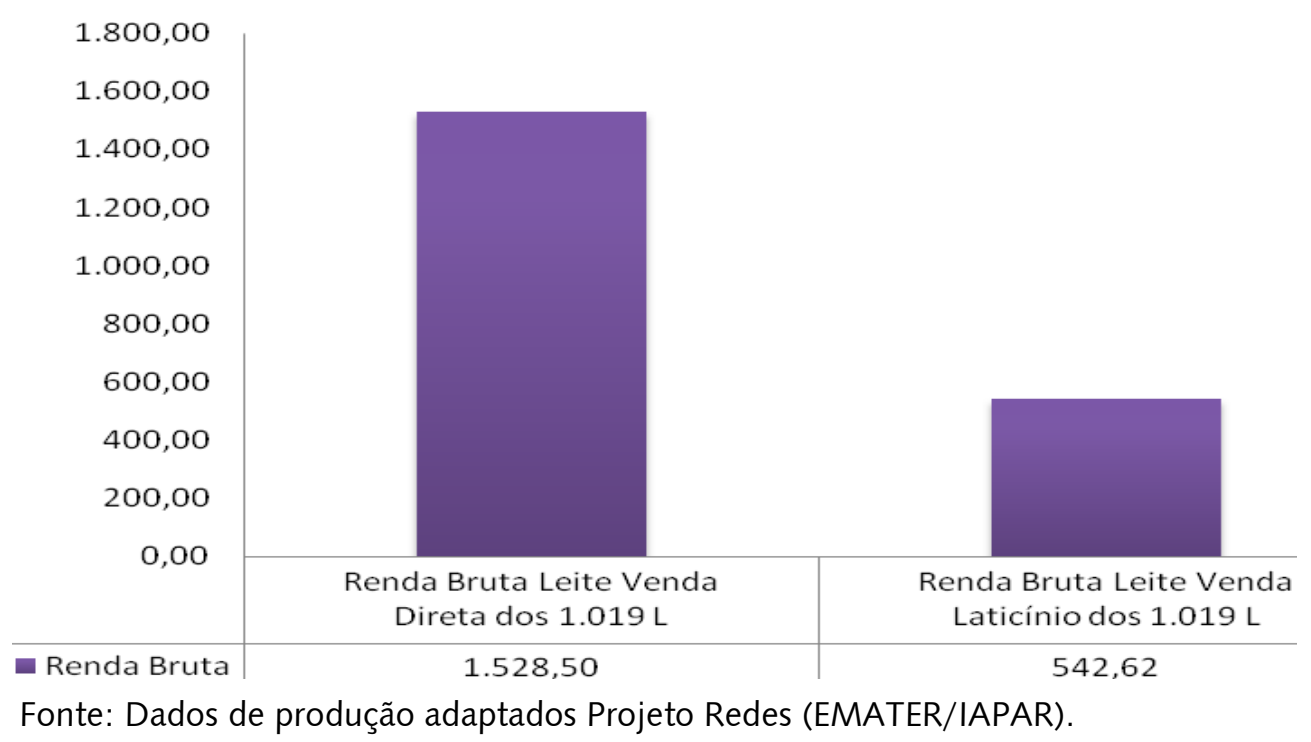


O uso do solo na propriedade é representado na Figura 1, composta principalmente por pastagem (44\%) e o restante por outras explorações. Pela visualização da Figura 2, observa-se a predominância da mão de obra voltada para a atividade leiteira do Produtor $A$.

Figura 1. Uso do Solo

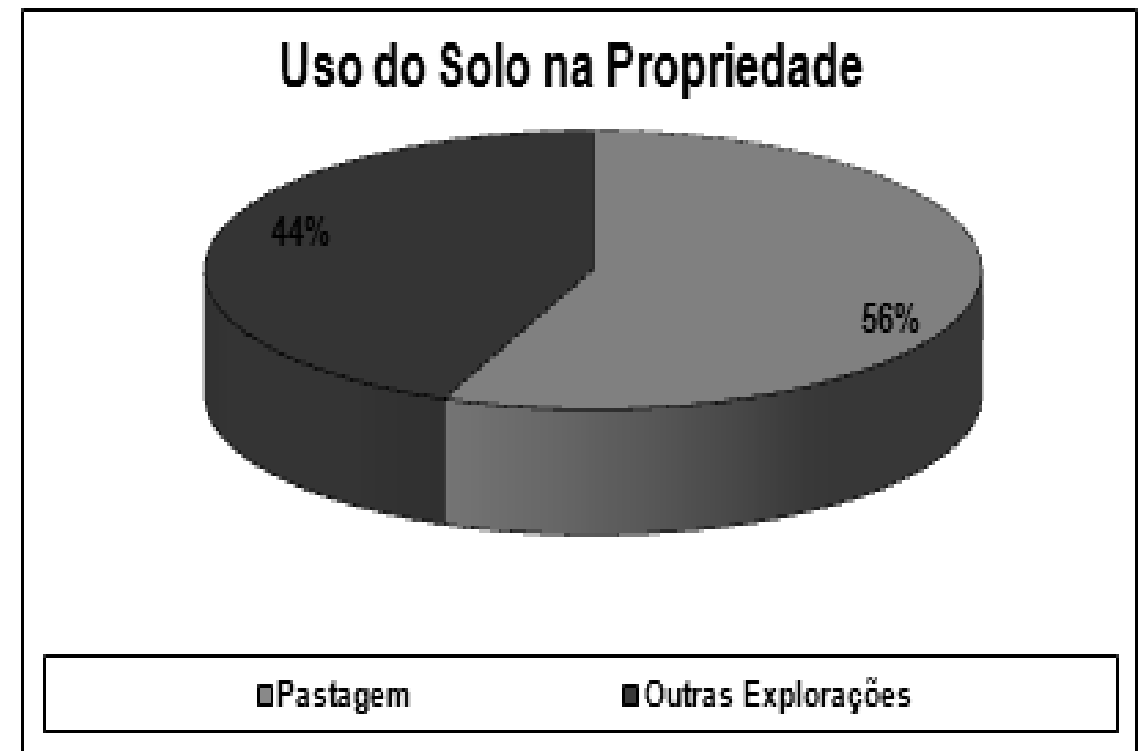

Fonte: Dados adaptados Projeto Redes (EMATER/IAPAR)

Figura 2. Uso de Mão de obra

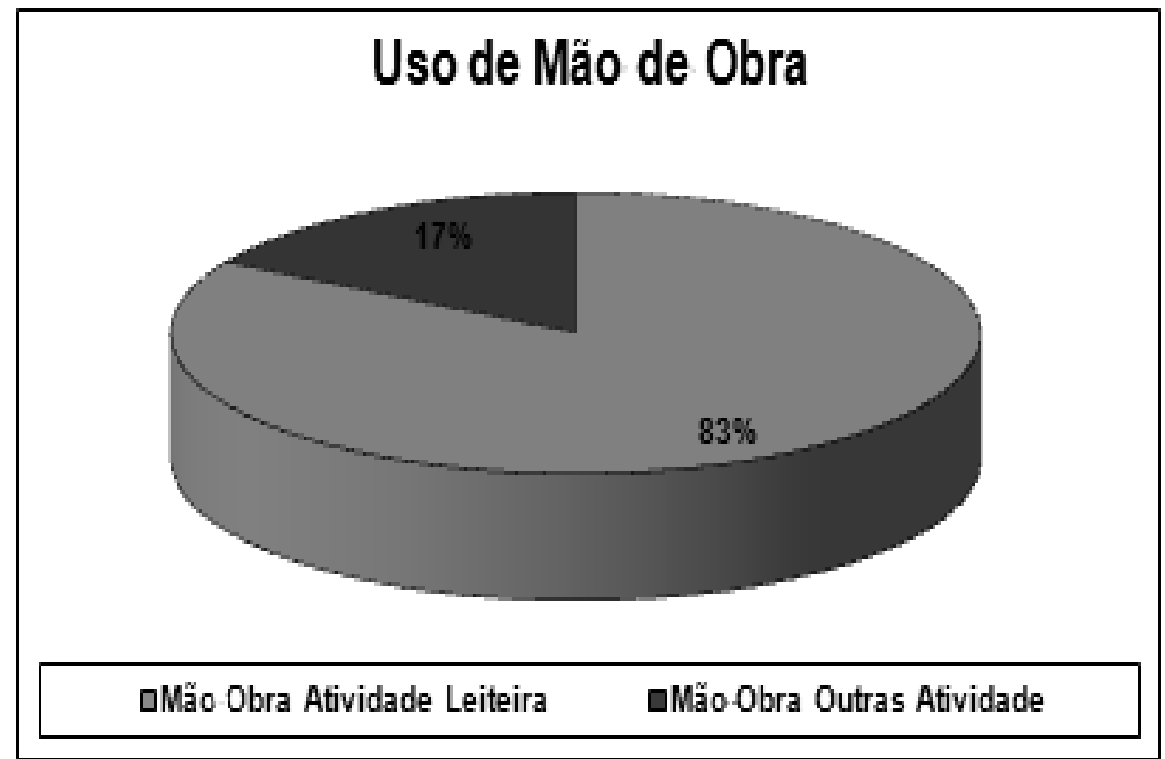

Fonte: Dados adaptados Projeto Redes (EMATER/IAPAR). 
Na Figura 3, observa-se a renda bruta da propriedade. Ressalta-se que a atividade leiteira participa com $50 \%$ da RB da propriedade, em comparação com as outras atividades, o que define a atividade como um meio de vida, uma vez que vem obtendo lucros, e se reproduzindo no campo, em que a atividade leiteira fornece metade de sua renda bruta comparando com todas as outras atividades desenvolvidas juntas.

Figura 3. Renda Bruta da Propriedade - Produtor A

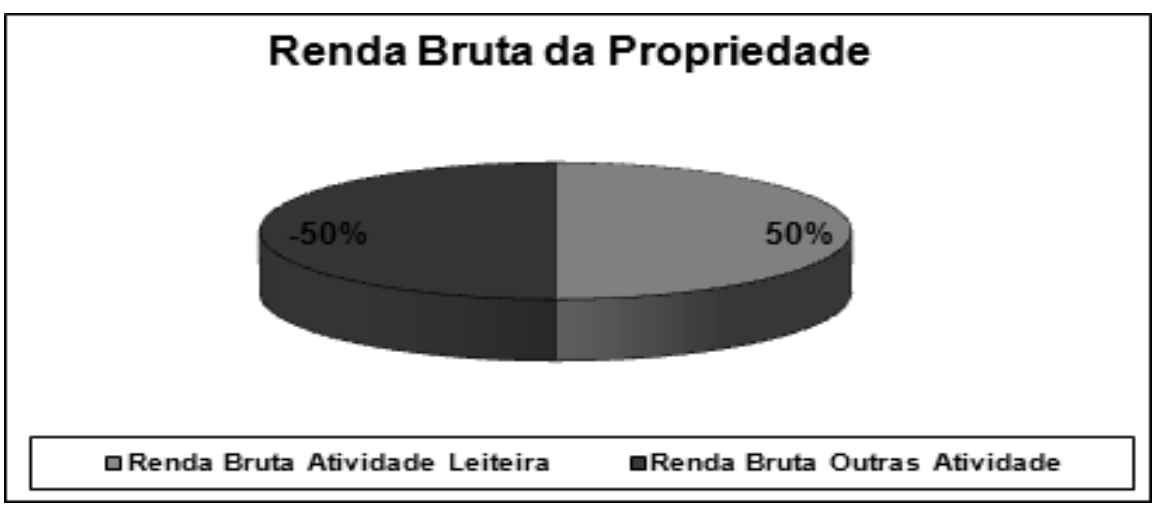

Fonte: Dados adaptados Projeto Redes (EMATER/IAPAR).

A Tabela 1 contém dados referentes à produção comercializada, ao custo total por litro, ao preço médio por litro, à margem líquida por litro e ao lucro líquido total mensal de Agosto de 2009 a Março de 2010, de acordo com os dados obtidos no Projeto REDES - EMATER/IAPAR, que possue um trabalho de acompanhamento de ambas as propriedades analisadas. Esses dados são importantes para a análise e comparação dos custos, receitas, e lucros obtidos, conforme a variação de preços do mercado seja do leite ou de insumos e commodities. Assim, a tabela permite a visualização de um balanço econômico da atividade leiteira para o produtor $\mathrm{A}$.

Tabela 1. Produção comercializada, custo total por litro, preço médio por litro, margem líquida por litro e lucro líquido total mensal de Agosto de 2009 a Março de 2010, Produtor A

\begin{tabular}{cccccccccc}
\hline & Ago/09 & Set/09 & Out/09 & Nov/09 & Dez/09 & Jan/10 & Fev/10 & Mar/10 \\
\hline $\begin{array}{c}\text { Produção } \\
\text { comercializada (Litros) }\end{array}$ & 1.100 & 1.220 & 1.220 & 933 & 900 & 766 & 813 & 1.200 \\
\hline Custo total R\$/L & 0,92 & 0,61 & 0,72 & 1,27 & 0,84 & 0,93 & 0,96 & 0,63 \\
\hline & & & & & & & & \\
Preço médio R\$/L & 1,5 & 1,5 & 1,5 & 1,5 & 1,5 & 1,5 & 1,5 & 1,5 \\
\hline & & & & & & & & \\
Margem líquida R\$/L & 0,58 & 0,89 & 0,78 & 0,23 & 0,66 & 0,57 & 0,54 & 0,87 \\
\hline $\begin{array}{c}\text { Lucro Líquido Total } \\
\text { (R\$) }\end{array}$ & 638,00 & $1.085,80$ & 951,60 & 214,59 & 594,00 & 436,60 & 439,02 & 0 \\
\hline
\end{tabular}

Fonte: dados não divulgados GPL - IAPAR/EMATER (2010). 
Agrega-se, também, a renda obtida pela venda ao laticínio que proporcionou a RB de $\mathrm{R} \$ 162,95$. Porém, observa-se que se o produtor dependesse exclusivamente da venda ao laticínio estaria fadado ao prejuízo, uma vez que os custos por litro permanecem sempre acima do que é pago pelo laticínio e, se não fosse a estratégia adotada pelo produtor, seu meio de vida estaria em grande risco.

O Gráfico 2 exibe a composição dos custos e da renda bruta com indicadores de renda bruta, custo variável, custo operacional, este mais a depreciação, custo operacional total e o custo total por litro de leite comercializado do produtor B, baseado nos dados obtidos no acompanhamento feito pelo projeto Redes de Referência executado em parceria pelo IAPAR e EMATER-PR.

Gráfico 2. Gráfico da composição dos custos e da renda bruta por litro de leite. Indicadores de Renda Bruta (RB), Custo Variável (CV), Custo Operacional (COE), COE + Depreciação, Custo Operacional Total (COT), Custo Total (CT) do Produtor A

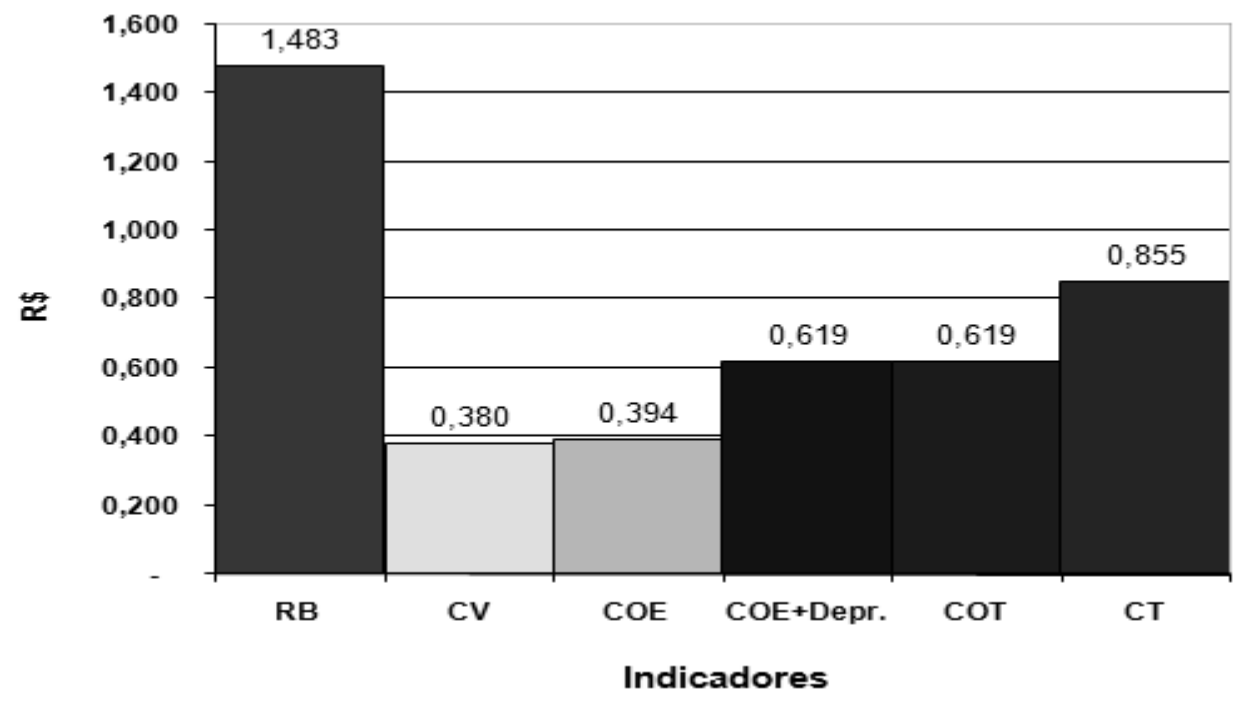

Fonte: dados não divulgados GPL - IAPAR/EMATER (2010).

Pode-se observar que o indicador do Custo Operacional Total - COT aproxima-se do Custo Total - CT, o que indica que este produtor é menos dependente de recursos externos por dispor de mão de obra familiar, pela produção ser basicamente a pasto, com suplementação, mas com custos menores que dietas baseadas em ensilados e rações. Isso é explicado por apresentar um baixo Custo Operacional - COE e de não haver necessidade de realizar financiamento para custear sua atividade. Não possui despesas relacionadas à manutenção e com menor depreciação (COE+Depreciação) da estrutura, assim como não tem custos com a pasteurização. Isso remete a esse produtor maior autonomia e menor investimento para se manter produzindo. No caso, opta em reduzir custos com os tratamentos térmicos e arrisca entregar o leite cru em domićlio, estando à mercê da fiscalização, porém, com uma elevada RB por litro 
de leite comercializado, a um custo total relativamente baixo, resultando num lucro líquido interessante para o agricultor.

\subsection{Estratégias do Produtor B}

O produtor $B$, assim como o produtor $A$, também é representativo na região Sudoeste do Paraná por apresentar área total de 9,6 ha, mão de obra familiar e produção de leite como a principal atividade da propriedade, feita basicamente a partir da pastagem e da silagem. O diferencial deste produtor em relação à maioria dos produtores do sudoeste é sua forma de comercialização. Com recursos oriundos de um programa estadual para uma associação foi construída uma unidade equipada para armazenagem e beneficiamento do leite, adequada às exigências do SIM. Como a associação não conseguiu se manter e a estrutura havia sido construída em sua propriedade, o produtor B continua a utilizá-la. Nessa unidade, o leite é embalado em saquinhos "barriga mole" e tratado termicamente. Nesse processo, o leite já embalado é submetido a um aumento de temperatura em banho-maria até a temperatura de pasteurização, a qual se mantém durante, ao menos, 30 minutos. Depois o leite é resfriado e permanece assim até ser comercializado nos mercados e pontos de venda. $O$ estabelecimento rural está localizado a 1,5 km de distância do aglomerado urbano. Essa proximidade influencia o desenvolvimento de uma estratégia alternativa de comercialização da produção por facilitar o acesso ao mercado local. Fator que pode dificultar as alternativas em casos de propriedades muito isoladas.

A estratégia de comercialização, fugindo da venda do leite aos grandes laticínios, realizando a embalagem e pasteurização na propriedade, vem a contribuir para a renda agrícola do produtor, uma vez que este irá auferir maiores preços na comercialização direta do seu produto, aos mercados, mercearias e outros pontos de venda.

O produtor B apresenta uma área total de 9,6 ha, sendo a Superfície Agrícola Útil - SAU igual a 7,0 ha. Nessa mesma área, o produtor possui 1,0 ha de pastagem perene, 1,21 ha de área para produção de silagem e esses mesmos 1,21 ha para a pastagem anual de inverno. Este produtor possui 30 animais, dos quais 15 vacas em lactação e duas vacas secas. Os outros estão distribuídos, sendo bezerras e novilhas entre três e 24 meses. De capital, o produtor possui um trator ano 70, uma caldeira para a pasteurização, além da ordenhadeira, galpão de fumo, paiol, estábulo e o laticínio. O produtor alimenta seus animais com silagem de milho, pastagem anual de inverno, podendo ser composta por aveia e azevém, e uma área com pastagem perene.

Nos custos, a silagem de milho é predominante no custo total da alimentação. O custo para a produção da silagem feita na safra 2009/2010 foi de $\mathrm{R} \$ 4.896,65$ incluindo todos os custos, desde o preparo do solo, os insumos (aproximadamente 52\% do custo da silagem), os tratos culturais e com o corte, compactação, lona, etc. Esse investimento de $\mathrm{R} \$ 4.896,65$ proporcionou uma produção de $132.000 \mathrm{Kg}$ de silagem, a um custo de 0,0379 R\$/Kg. A pastagem 
anual de inverno teve um custo de $R \$ 400,00$ para implantação, incluindo os insumos e os tratos culturais, e proporcionou a produção de $20.000 \mathrm{Kg}$ de pasto disponível para as vacas, a um custo de $R \$ 0,0200 / \mathrm{Kg}$. Além dos custos com outros suplementos, como sal mineral, medicamentos, assistência veterinária, etc. Dependendo da época do ano varia o alimento e a quantidade ofertada. Existem períodos críticos no ano em que existe pouca disponibilidade de pastagem perene e a pastagem anual de inverno ainda não se encontra plenamente desenvolvida (ou já senescida) que possibilite a alimentação das vacas (vazio forrageiro). São períodos em que a quantidade de silagem oferecida aumenta, chegando a $15.000 \mathrm{Kg}$ (agosto de 2009), $12.000 \mathrm{Kg}$ (setembro de 2009), $10.000 \mathrm{Kg}$ (outubro), diminuindo a $5.000 \mathrm{Kg}$ em novembro de 2009. No mês de dezembro, de acordo com a disponibilidade de silagem e de pasto perene, pode ou não ser ofertada a silagem, dando preferência em ofertar o alimento mais barato para obter o melhor retorno possível. Em janeiro, fevereiro e março de 2010, a quantidade ofertada ficou em $5.000 \mathrm{Kg} / \mathrm{mês}$, o que representa um custo de $\mathrm{R} \$ 189,26 /$ mês de silagem. $\mathrm{Na}$ dieta, também são fornecidos resíduos, como a casca de soja e farelo de milho, para a alimentação, variando a quantidade conforme o preço e a necessidade. Porém, em média, são fornecidos $1.350 \mathrm{~kg} /$ mês a um custo médio de $\mathrm{R} \$ 0,39 / \mathrm{Kg}$ de resíduo, ou seja, a um custo mensal de $R \$ 526,50$. Esse custo é reduzido em meses de maior oferta, principalmente durante a safra, quando os preços podem chegar a $R \$ 0,28 / \mathrm{Kg}$. As bezerras recebem ração inicial para bezerras em uma quantidade média de $40 \mathrm{Kg} / \mathrm{mês}$.

O produtor tem uma produção média de leite de 3.700 litros/mês, que é embalado, pasteurizado e vendido no mercado local, com uma produtividade média, por vaca lactante, de 8,4 litros/dia. Quase a totalidade do que é produzido é vendido, considerando uma pequena parte para autoconsumo e fabricação de derivados e, também, para o consumo familiar. O preço de venda médio obtido por esse produtor nos meses analisados é de $R \$ 1,44$ por litro de leite, o que proporciona uma RB de $\mathrm{R} \$ 5.698,00$, como se observa no Gráfico 3. Na venda direta, o produtor B mantém o preço constante durante todo o ano, assim, seu lucro não é dependente do preço do mercado. Ao preço de $R \$ 0,75$ por litro, os 3.700 litros resultariam em uma $R B$ de $R \$ 2.775,00$, ou seja, pela estratégia utilizada, ele pasteuriza e realiza a venda direta resultando num aumento de 205,3\% na RB do leite vendido ao laticínio. Comparando com a venda direta, há uma diferença de $R \$ 2.923,00$ de $R B$, sem considerar aqui os custos de produção e custos com a pasteurização. É evidente que a estratégia de comercialização agrega valor ao seu produto e pode, assim, obter maior renda em sua propriedade. Melhor visualizado no Gráfico 3. 
Gráfico 3. Gráfico hipotético comparando a RB obtida do leite vendido diretamente ao consumidor pelo produtor B com a RB do mesmo leite vendido ao laticínio

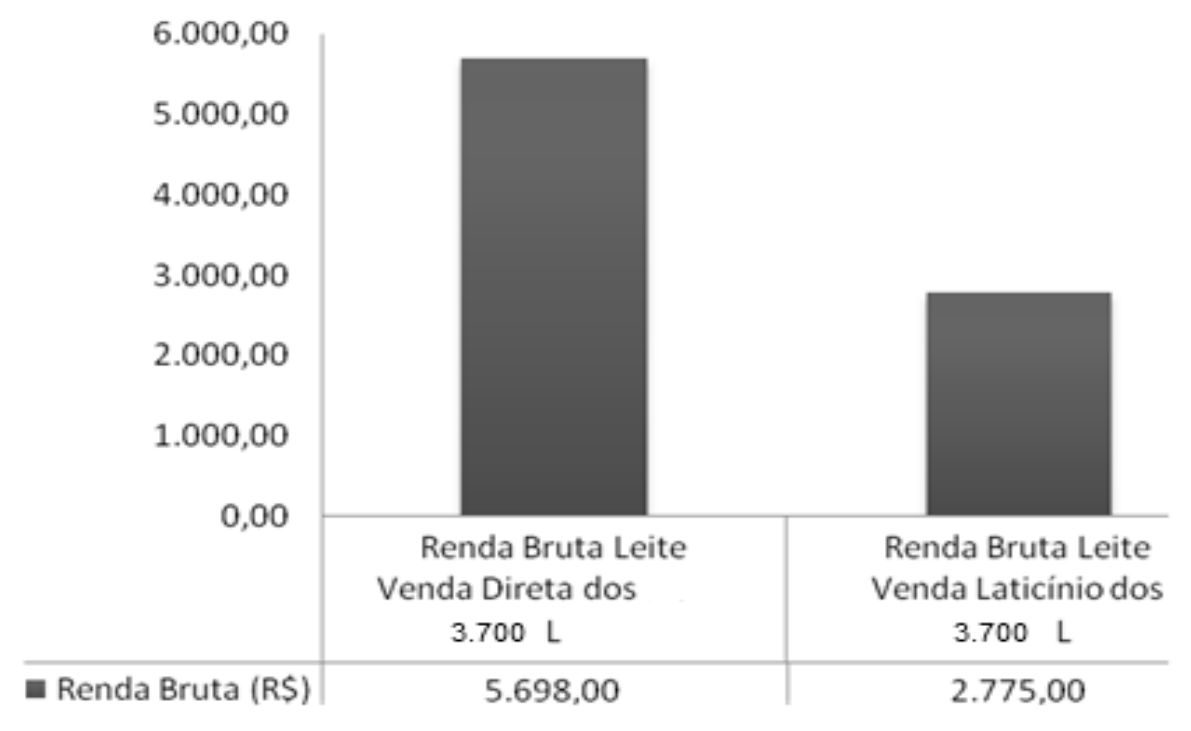

Fonte: Dados de produção adaptados Projeto Redes (EMATER/IAPAR).

As figuras abaixo $(4,5$ e 6$)$ ilustram o uso do solo assim como a renda bruta obtida e o uso de mão de obra na propriedade do produtor $B$, aspectos que influenciam na estratégia adotada pelos produtores.

Figura 4. Uso do Solo

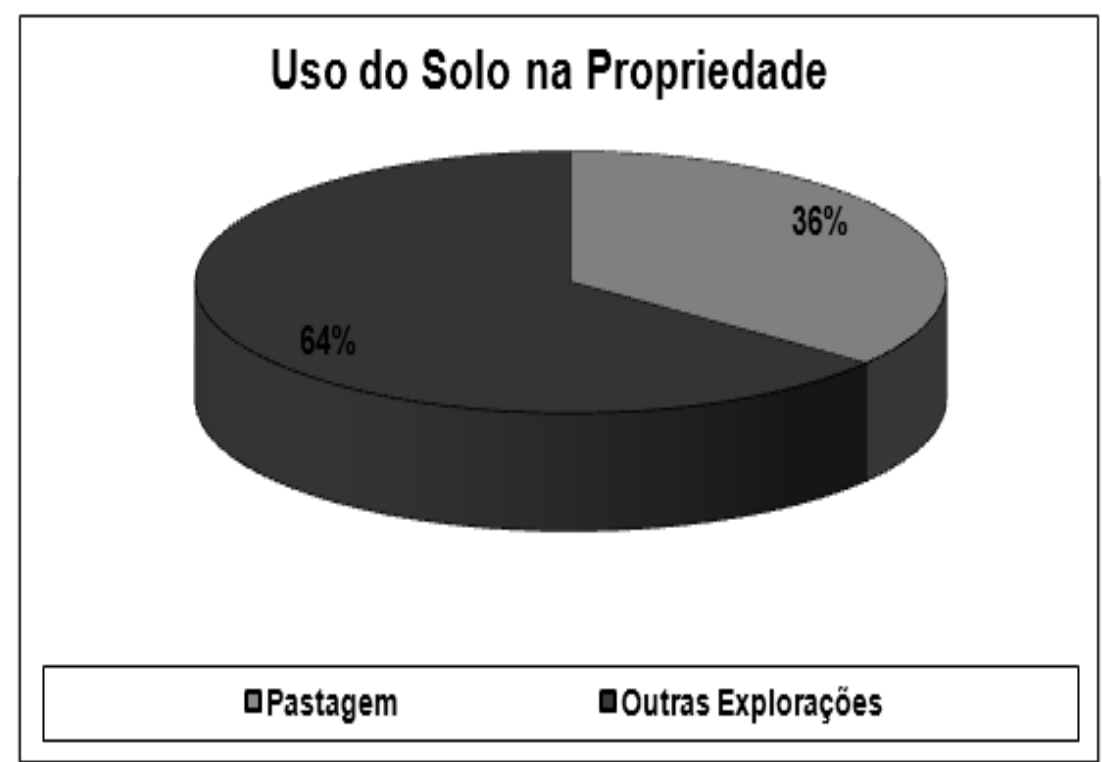

Fonte: Dados adaptados Projeto Redes (EMATER/IAPAR). 
Figura 5. Renda Bruta

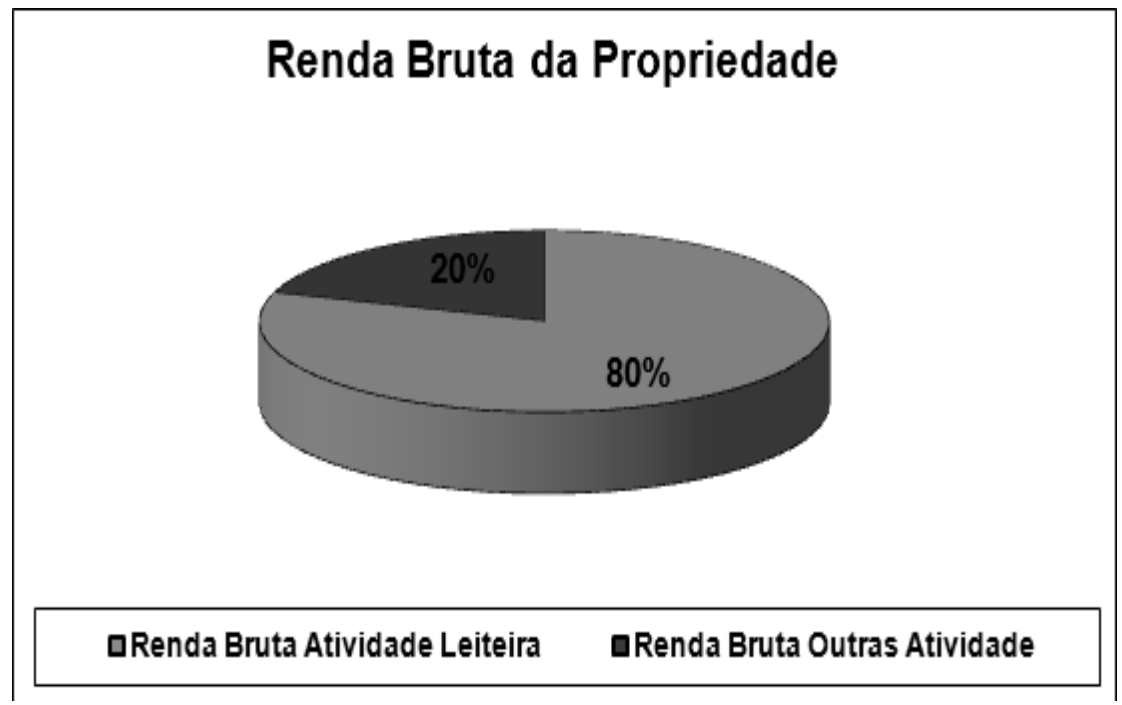

Fonte: Dados adaptados Projeto Redes (EMATER/IAPAR).

Figura 6. Uso de Mão de obra.

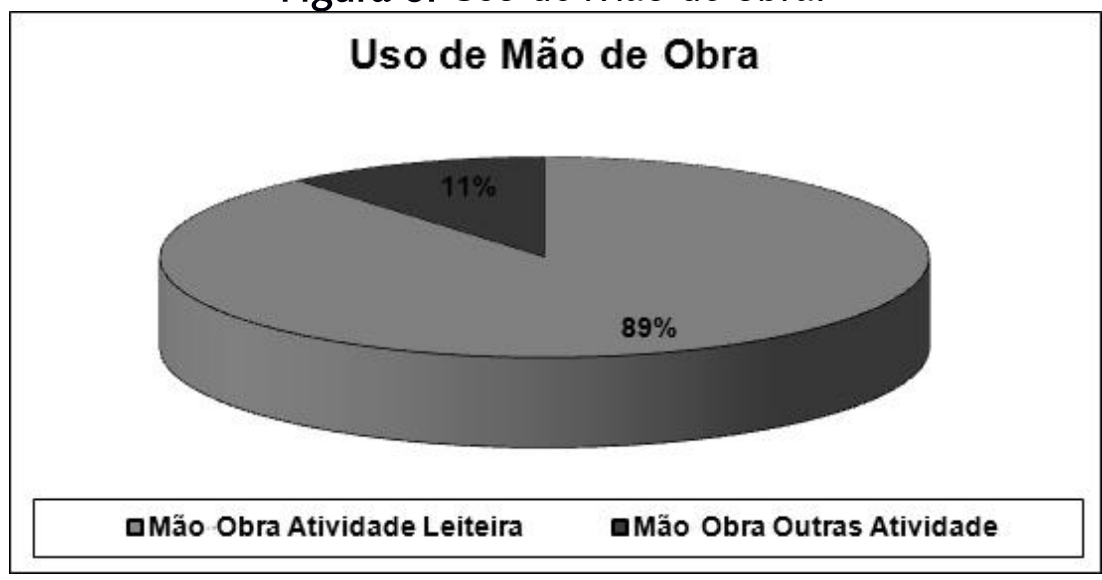

Fonte: Dados adaptados Projeto Redes (EMATER/IAPAR).

Antes da pasteurização, o leite é submetido a uma desnatadeira, que padroniza a gordura e retira a nata que também é submetida à pasteurização e comercializada. Por possuir estrutura adequada para obter alvará do S.I.M., o agricultor pode comercializar seu leite em mercearias, mercados, assim como, atender ao programa do governo do Paraná - o "Leite das Crianças" - ou pelo Programa de Aquisição de Alimentos - PAA, que atende creches, escolas e hospitais do Município de Verê. Na Tabela 2 abaixo, pode-se visualizar a produção comercializada e os aspectos econômicos analisados. 
Tabela 2. Produção comercializada, custo total por litro, preço médio por litro, margem líquida por litro e lucro líquido total mensal de Agosto de 2009 a Março de 2010 - Produtor B

\begin{tabular}{ccccccccc}
\hline & ago/09 & set/09 & out/09 & nov/09 & dez/09 & jan/10 & fev/10 & mar/10 \\
\hline $\begin{array}{c}\text { Produção } \\
\text { comercializada(L) }\end{array}$ & 3.700 & 4.000 & 4.004 & 3.764 & 3.776 & 3.165 & 3.607 & 3.509 \\
\hline Custo total R $\$ / L$ & 1,13 & 1,05 & 1,04 & 1,13 & 0,85 & 1,14 & 1 & 0,89 \\
\hline Preço médio R $\$ / L$ & 1,41 & 1,46 & 1,48 & 1,47 & 1,47 & 1,39 & 1,45 & 1,37 \\
\hline $\begin{array}{c}\text { Margem líquida } \\
\text { R } \$ / L\end{array}$ & 0,28 & 0,41 & 0,44 & 0,34 & 0,62 & 0,25 & 0,45 & 0,48 \\
\hline
\end{tabular}

Lucro Líquido Total

$\begin{array}{llllllll}1.036 & 1.640 & 1.761,76 & 1.279,76 & 2.341,12 & 791,3 & 1.623,15 & 1.684,32\end{array}$

Fonte: dados não divulgados GPL - IAPAR/EMATER (2010).

O gráfico 4 exibe a composição dos custos e da renda bruta com os indicadores de RB, custo variável, custo operacional, este mais a depreciação, custo operacional total e o custo total do produtor $B$, baseado nos dados obtidos no acompanhamento feito pelo projeto Redes de Referências (IAPAR/EMATER-PR).

Gráfico 4. Gráfico da composição dos custos e da renda bruta por litro de leite. Indicadores de Renda Bruta (RB), Custo Variável (CV), Custo Operacional (COE), COE + Depreciação, Custo Operacional Total (COT), Custo Total (CT) do Produtor B

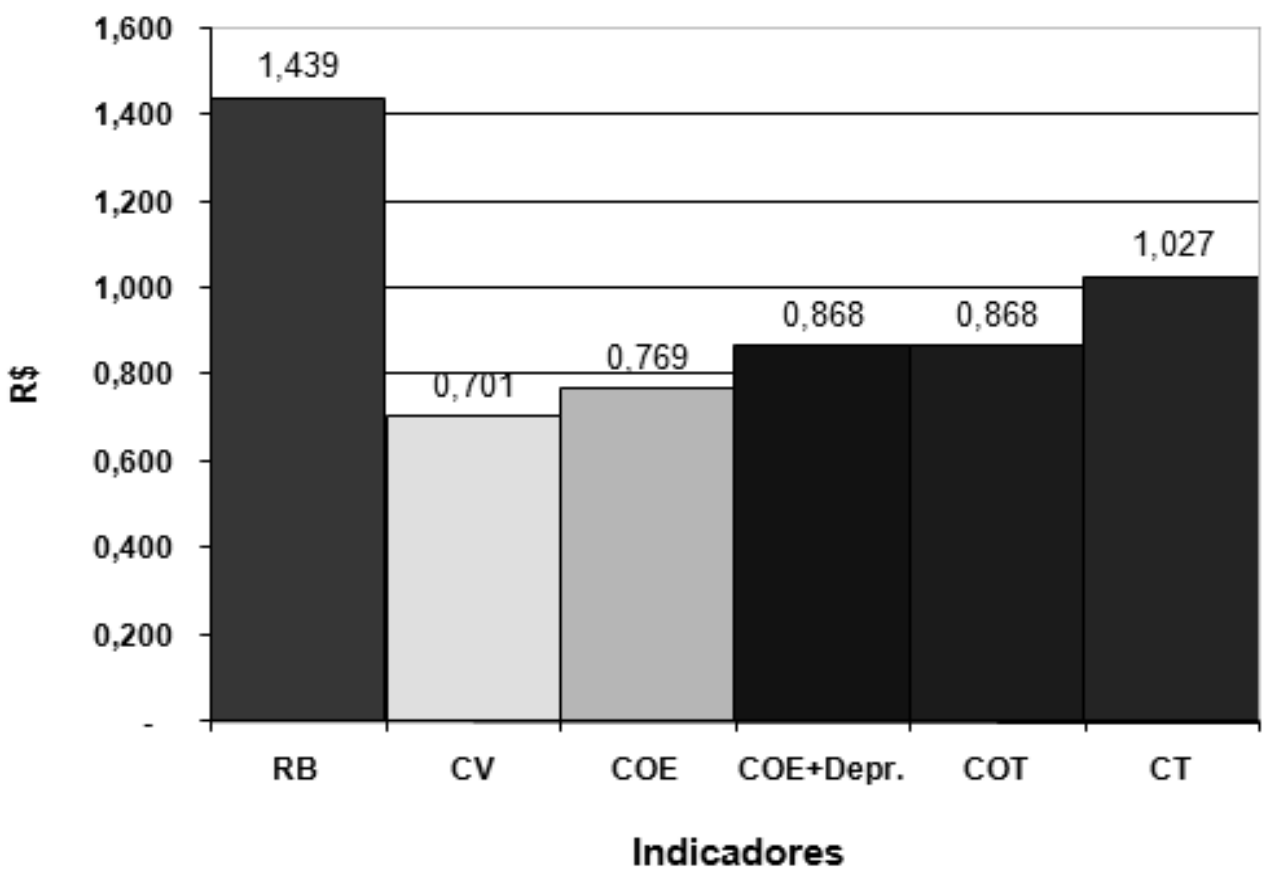

Fonte: Dados de produção adaptados Projeto Redes (EMATER/IAPAR).

Aqui também pode-se observar que o indicador do COT aproxima-se do CT. Contudo, comparando com o produtor A, o COT do produtor B é maior, indicando que este tem mais custos operacionais e, consequentemente, maior CT, 
destacando, principalmente, os custos com a pasteurização e embalagem, com mão de obra contratada, etc. Destaca-se que, apesar de ter um custo maior para poder comercializar sua produção, este produtor pode, assim, acessar mercados legalmente e, também, os programas do governo como o compra direta pelo "Programa de Aquisiçãa de Alimentos - PAA", "Leite das Crianças" e "Merenda Escolar", ressaltando a importância desses programas no acesso dos produtores familiares ao mercado, possibilitando o encurtamento das cadeias produtivas, gerando mais empregos e renda no meio rural.

\section{CONSIDERAÇÕES FINAIS}

Os agricultores que fazem a venda direta apresentaram uma constante preocupação com a qualidade do leite, procurando na medida do possível, adaptarem-se as novas tecnologias de produção e práticas de manejo que visem à maior qualidade e segurança de seus produtos aos seus consumidores. Tal cuidado se explica na busca por evitar problemas de intoxicação e consequente perda da confiança de sua rede de consumidores. Isso reflete e reforça a responsabilidade do produtor perante seus consumidores.

Em relação à renda obtida com a atividade leiteira, observa-se que o produtor $\mathrm{A}$ apresenta uma maior taxa de retorno financeiro comparativamente ao produtor B, uma vez que, ao entregar de porta em porta sem realizar o tratamento térmico, vende com um custo menor e um preço previamente fixado aos seus clientes, subtraindo custos com o tratamento e manutenção de maquinário e mão de obra para embalagem. E o produtor $B$, apesar do custo da pasteurização e embalagem, também agrega valor beneficiando e comercializado no mercado local, além de atender a programas do governo, como o Leite das Crianças. Evidencia-se que as estratégias de comercialização adotadas pelos dois produtores Ihes proporcionam um maior rendimento em comparação com outros produtores que se inserem em cadeias longas.

Entretanto, mesmo podendo oferecer um produto de melhor qualidade, o produtor A está fora do exigido por lei, tendo sua estratégia ameaçada pela fiscalização municipal. Porém, se o quesito legal da qualidade permitisse adotar os princípios de BPA, esse tipo de produtor poderia ter visibilidade no mercado ao invés de ser clandestino. Ainda assim, há muito que se discutir, porém, é imprescindível que a pesquisa e extensão resgatem a possibilidade legal de responsabilizar o produtor pela qualidade do leite e não somente ao processamento agroindustrial.

A legislação brasileira, no que diz respeito às exigências sanitárias requeridas, é extremamente rígida e nem por isso, eficiente. Na Europa, após as várias crises de segurança alimentar, todos os países concordaram que novas medidas deveriam ser tomadas para evitar incidentes de segurança alimentar e melhor proteger a saúde dos seus cidadãos, treinando e transferindo tecnologia aos seus produtores, procurando não ser um obstáculo ao desenvolvimento da atividade e, sim, uma ferramenta para obter melhores rendimentos.

Assim, no Brasil há uma necessidade de se discutir a responsabilidade sobre a segurança dos alimentos. Essa responsabilidade é de cada pessoa que trabalha 
com o alimento, desde a obtenção da matéria prima até a casa do consumidor, exigindo adoção de boas práticas e que estes estejam cientes dos riscos e, assim, da sua responsabilidade. Isso deve ocorrer aliado à discussão da legislação brasileira, para que esta seja, ao mesmo tempo, eficiente e menos excludente, mas objetivando sempre a qualidade do que é produzido.

Destaca-se a importância que a atividade leiteira tem para os agricultores familiares da região Sudoeste do Paraná, uma vez que tem possibilitado rentabilidade mesmo em pequenas áreas de terra e melhorando a qualidade de vida no meio rural. Por isso, é necessário investimento em pesquisa que resulte no desenvolvimento de toda a cadeia do leite, iniciando pela melhoria da qualidade da matéria-prima, que ocorrerá a partir do incentivo de preços melhores para o leite que apresentar qualidade superior. Além disso, é importante o fomento e auxílio às pequenas e médias agroindústrias familiares, associações e cooperativas. Incentivo à indústria, explorando o mercado do leite, investindo em marketing no setor, inovando produtos e abrindo mercados, facilitando o escoamento da produção e garantindo a comercialização. Isso permitiria que ocorresse 0 desenvolvimento de toda a cadeia do leite $\mathrm{e}$, consequentemente, dos produtores $\mathrm{e}$ de toda a região Sudoeste.

O estudo sobre as diferentes estratégias adotadas permite reconhecer similitudes na cadeia produtiva, possibilitando o desenvolvimento de políticas públicas voltadas para esses produtores, por meio do estudo de suas demandas, buscando facilitar o acesso aos mercados, proporcionando maior rentabilidade e um produto final de valor agregado e qualidade superior, beneficiando também os consumidores que adquirem um produto de excelente qualidade e seguro. Sendo assim, o estudo da atividade é de suma importância para o desenvolvimento da região Sudoeste do Paraná e dos produtores que utilizam dessa estratégia para sobreviverem.

Uma estratégia que tem se destacado é a atuação sobre os mercados locais, que tem proporcionado uma reconexão do campo com a cidade, do produtor com o consumidor, o que reflete em maior rentabilidade no campo, pela diversificação, agregação de valor, e o consumidor compra um produto de melhor qualidade, íntegro e de origem conhecida. Cabe ao Estado e aos legisladores tomarem conhecimento da realidade e das dificuldades vividas no campo para, assim, poderem legislar de forma eficiente e includente, mas garantindo a segurança e a qualidade.

\section{REFERÊNCIAS}

ABRAMOVAY, R. O Capital Social dos Territórios: repensando o desenvolvimento rural. Economia Aplicada, v. 4, n. 2, abril/junho 2000.

ALVES, A. R. et al. BOLETIM SETORIAL DO AGRONEGÓCIO No 03 Bovinocultura Leiteira.SEBRAE/FAEPE/SENAR, 2010. Disponível em: $<$ http://200.249.132.92:8080/ notitia/dowload/Boletim-Bovinocultura.pdf > Acesso em: 01 jun. 2011 
BATTAGLINI, A. P. P., et al. A extensão universitária na melhoria da qualidade do leite na região Central do Paraná, Brasil. 2009.

BIGATON, A. L. W., POLO, E. F. \& ESCRIVÃO FILHO, E. Gestão estratégica da informação: estudos em pequenas empresas. SEGeT - Simpósio de Excelência em Gestão e Tecnologia, 2007.

BRASIL. MAPA - MINISTÉRIO DA AGRICULTURA, PECUÁRIA E ABASTECIMENTO. Instrução Normativa $n^{\circ}$ 51, de 18 de setembro de 2002. Disponível em:

<http://extranet.agricultura.gov.br/sislegisconsulta/consultarLegislacao.do? operacao=visualizar\&id=8932> Acesso em: 20 jan. 2010.

DERAL. Departamento de Economia Rural, da Secretaria do Estado de Agricultura e do Abastecimento do Paraná. Produção Agropecuária. Disponível em: $<$ http://www.agricultura.pr.gov.br/modules/conteudo/conteudo.php?conteud $\mathrm{o}=137>$ Acesso em: 08 jun. 2015.

DEVES, O.D. \& FILIPPI, E.E. A segurança alimentar e as experiências das políticas agro-alimentares locais no fortalecimento da agricultura familiar. IV CONGRESSO INTERNACIONAL DE LA RED SIAL. Argentina Mar Del Plata, 27 al 31 de Octubre de 2008.

ESCHER, F. "Os assaltos do moinho satânico nos campos e os Contramovimentos da agricultura familiar": Atores sociais, instituições e desenvolvimento rural no Sudoeste do Paraná. Dissertação de Mestrado Série PGDR, 2011.

FERREIRA, A. D. D., BRANDENBURG, A., RODRIGUES, A. S., SANTOS, E. B., PINHEIRO, G. e SILVA, O. H. da,. Resistência e empoderamento no mundo rural. Estud.soc.agric, Rio de Janeiro, vol. 15, no. 1, 2007: 123-159.

IBGE. Instituto Brasileiro de Geografia e Estatística. Produção Pecuária Municipal. 2008. Disponível em: <http://www.ibge.gov.br/home/estatistica/economia/ppm/2008/comentario s.pdf> Acesso em: 30/05/2010.

IBGE. Instituto Brasileiro de Geografia e Estatística. Produção Pecuária Municipal. Produção Pecuária Municipal. 2013. Disponível em: <http://ibge.gov.br/home/estatistica/economia/ppm/2013/default_xls_grandes_ regioes.shtm>

LAMARCHE, Hughes, et all A agricultura familiar: comparação internacional. I Uma realidade multiforme.Trad. Tijiwa, Ângela M. N. Campinas, SP. UNICAMP, 1993.

PLOEG, J. D. van der. Resistance of the third kind and the construction of sustainability. Paperpresented to ESRS Conference, 23rd of August 2007, 
Wageningen. Disponível em: <www.jandouwevanderploeg.com>. Acesso em 27 dez. 2011.

PLOEG, J. D. van der. Trajetórias do desenvolvimento rural: pesquisa comparativa internacional. Sociologias, Porto Alegre, ano 13, no 27, p. 114-140, 2011.

WILKINSON, J. \& MIOR, L. C.. Setor informal, produção familiar e pequena agroindústria: interfaces. Estudos Sociedade e Agricultura, n.13, p. 29-45 1999.

ZOCCAL, R.; GOMES, A.T.; CARVALHO, L.A. O agronegócio do leite: análise e perspectivas. Congresso Brasileiro de Economia e Sociologia Rural, 42, Cuiabá, 2004.

Submetido em 21/04/2013

Aprovado em 02/06/2015

Sobre os autores

Vinícius Deotan Coletti

Eng. Agronomo, Mestre em Desenvolvimento Regional, SEAB (Secretaria de Estado da Agricultura e do Abastecimento - Paraná)

Endereço: Rua Souza Naves, 077. 85660-000 - Dois Vizinhos - PR - Brasil.

E-mail: vdcoletti@seab.pr.gov.br

\section{Miguel Angelo Perondi}

Eng. Agronomo, Doutor em Desenvolvimento Rural, UTFPR (Campus Pato Branco).

Endereço: Rodovia do Conhecimento - Km 1, Bom Retiro. 85503-390 - Pato Branco - PR - Brasil.

E-mail: perondi@utfpr.edu.br 